ZOOLOGIA 31 (1): 88-96, February, 2014

http://dx.doi.org/10.1590/S1984-46702014000100010

\title{
Taxonomic notes of Hemixantha (Diptera: Richardiidae) with description of a new species from the Amazon Region
}

\author{
Lisiane Dilli Wentd \& Rosaly Ale-Rocha
}

Instituto Nacional de Pesquisas da Amazônia, Coordenação de Pesquisas em Biodiversidade. Avenida André Araújo 2936, Petrópolis, 69011-970 Manaus, Amazonas, Brasil. E-mail: lisidilli@yahoo.com.br; alerocha@inpa.gov.br

\begin{abstract}
Richardiidae is represented by ca. 180 species in 33 genera. A new species of Hemixantha, now totaling 20 species, is described from the Amazon Region, state of Pará, Brazil, and from Teoponte, Bolivia. Hemixantha maculosa sp. nov., H. picta Hennig, 1937 and H. pulchripennis Hendel, 1911 are richardiids known to have an extensively banded wing pattern. Hemixantha maculosa sp. nov. represents the first record of Hemixantha from the state of Pará and this species can be distinguished from H. picta and H. pulchripennis by anepisternum and dorsal half of anepimeron bright yellow and vein $\mathrm{R}_{2+3}$ slightly sinuous. Besides the hyaline areas on the wing of $H$. maculosa are very distinct from these other species, as follows: (1) subtrapezoidal median area in cell cua ${ }_{1}$ extended anteriorly to vein $\mathrm{M}_{1}$, separated from hyaline area in cell $\mathrm{dm}$; (2) two oblique areas from costal margin almost to or beyond vein $\mathrm{R}_{4+5^{\prime}}$ one proximal to and one distal to level of crossvein $r-m$; (3) a circular area on basal part of cell $r_{4+5}$ and (4) a triangular area on basal region of cell $\mathrm{m}_{1}$. An identification key, diagnoses, description and redescriptions, and illustrations to the species of Hemixantha with an extensively banded wing pattern are provided.
\end{abstract}

KEY WORDS. Hemixantha maculosa sp. nov.; Neotropical; new record; terminalia; wing.

Richardiidae is a family of tephritoid Diptera represented by ca. 180 species in 32 genera that are allocated to two subfamilies: Richardiinae and Epiplateinae (HANCOCK 2010). The family is essentially Neotropical in distribution.

Of the two subfamilies, Richardiinae is the most diverse, encompassing more than $90 \%$ of the species described (STEYSKAL 1968). Even though many morphological differences can be found among the included genera, a preliminary phylogenetic analysis indicates that the subfamily is a strongly-supported monophyletic group (WendT \& Ale-Rocha, unpublished data). From a historical perspective, the taxonomy of the Richardiinae has been relatively poorly studied but interest in it has been revived in a few recent contributions, as follows: new taxa were described (Perez-Gelabert \& Thompson 2006, Carvalho et al. 2011, Alencar et al. 2013); a genus was re-described (Wendt \& AleRосна 2012) and, especially important, a key to all genera (HANCock 2010) was published.

In Brazil, 13 genera and 60 species of Richardiinae have been recorded but only 16 species are known to occur in the Brazilian Amazon (Aczél 1950, Steyskal 1968, Alencar et al. 2013). Of these, only five are known from the state of Pará: Beebeomyia flavimaculata (Hennig, 1937), Odontomera ruficauda Hendel, 1936, Ozaenina moderata Hennig, 1938, Richardiodes rectinervis Hendel, 1912, and Setellia pernix (Gerstaecker, 1860) (SteysKal 1968). This number, however, probably underestimates the real diversity of the group in the region.
At the beginning of the $20^{\text {th }}$ century, Hendel (1911a) and HeNNIG $(1937,1938)$ published important taxonomic contributions, with new records, descriptions and re-descriptions of species of Richardiidae, especially from Bolivia. Thus the fauna of richardiids from Bolivia is relatively well known, where 13 genera and 35 species have been recorded (STEYsKal 1968).

Richardiids usually have the wing hyaline or yellowish, with round or transverse spots at the base, apex and/or median region. However, five known species, Schnusimyia parvula Hendel, 1911, Richardia tephritina Enderlein, 1912, R. schnusei Hendel, 1911, Hemixantha picta Hennig, 1937 and $H$. pulchripennis Hendel, 1911, and the new species herein described, have spots on the wing forming an extensively banded pattern that superficially resembles the bands of some species of Tephritidae, for instance Parastenopa Hendel, 1914 and Rhagoletis Loew, 1862. There are some hypotheses about the function of the wing banded patterns in tephritoids (e.g., SIVINSKI \& Webb 1986, Mather \& Roitberg 1987, Sivinski \& Pereira 2005). For instance, tephritid species with markings on the wings are considered jumping spider mimics (e.g., GreENE et al. 1987) or wasp mimics (e.g., WHITE 1999). However, in most cases, the adaptive significance of the markings remains obscure (SIVINSKI 1999).

Hemixantha was proposed by Loew (1873) as a monotypic genus for $H$. spinipes. Thereafter, 19 species and one subspecies were described in the genus, especially by Hendel (1911a) and 
HenNig $(1937,1938)$. However, the last contribution describing a new species of Hemixantha dates back to the 1930s (HeNNIG 1938). The genus occurs from Costa Rica to southeastern Brazil, but most species are recorded from the Amazon Region, especially from Brazil, Peru and Bolivia (SteYsKal 1968).

In this paper, we describe and illustrate a new species of Hemixantha with an extensively banded wing pattern, from the state of Pará, Brazil, and La Paz Province, Bolivia. The new species represents the first record of the genus from Pará. We also compare $H$. maculosa sp. nov. with the two other species of the genus with patterns on the wings: $H$. picta and $H$. pulchripennis. Furthermore, we provide diagnoses and redescriptions for the latter two species. Sexual dimorphism in the wing patterns is also demonstrated for the first time.

\section{MATERIAL AND METHODS}

Specimens listed in the material examined section belong to the following institutions (curator name within parenthesis): INPA - Instituto Nacional de Pesquisas da Amazônia, Manaus, Amazonas, Brazil (Augusto Loureiro Henriques); MPEG - Museu Paraense Emílio Goeldi, Belém, Pará, Brazil (Orlando Tobias Silveira); MZSP - Museu de Zoologia da Universidade de São Paulo, São Paulo, Brazil (Carlos José Einicker Lamas); SMT - Senckenberg Natural History Collections Dresden, Museum of Zoology (Museum für Tierkunde), Dresden, Germany (Uwe Kallweit); USNM - National Museum of Natural History, Smithsonian Institution, Washington, D.C., USA (Allen Lee Norrbom).

The terminology for the external morphological characters follows Cumming \& Wood (2009), except the terminology for the terminalia, which follows Whiтe et al. (1999).

When providing label data of the type material, we separated individual lines with a forward slash (/) and individual labels are cited within quotation marks. Information within square brackets (口) indicates additional data that are not present on the specimen labels.

\section{TAXONOMY}

Identification key to the species of Hemixantha with an extensively banded wing pattern

1. Wing cell $r_{4+5}$ with a circular hyaline sub-basal area (Fig. 1, indicated with red arrow); vein $\mathrm{R}_{2+3}$ slightly sinuous (Fig. 1). Anepisternum and dorsal half of anepimeron bright yellow (Fig. 5). Brazil: Pará; Bolivia: La Paz Province .......

\section{H. maculosa sp. nov.}

$1^{\prime}$. Wing cell $\mathrm{r}_{4+5}$ with hyaline sub-basal area, but never circular in shape (Figs 2 and 3, indicated with red arrows); vein $\mathrm{R}_{2+3}$ straight (Figs 2 and 3). Anepisternum and anepimeron bright brown (Fig. 23)

2. Coxae, basal half or more of fore femur, and mid and hind tibiae dark brown. Wing with wide oblique hyaline area at middle, from costal margin to cell $\mathrm{dm}$, separated from subtriangular hyaline area at middle of cell cua ${ }_{1}$ (Fig. 4, indicated with black arrow) Brazil: Amazonas ....

H. pulchripennis Hendel

2 '. Fore coxa, fore femur, and mid and hind tibiae entirely yellow (Fig. 23). Wing (at least in female) with two complete transverse hyaline areas, and one across middle from cell $r_{1}$ to cell $\mathrm{cu}_{1}$ slightly oblique, and another on apical third of wing (Fig. 2). Bolivia ..... H. picta Hennig

\section{Hemixantha maculosa sp. nov.}

\section{Figs 1, 5-12, 15-22}

Diagnosis. Hemixantha maculosa sp. nov. differs from $H$. picta and $H$. pulchripennis in the following features: anepisternum and dorsal half of anepimeron bright yellow and vein $\mathrm{R}_{2+3}$ slightly sinuous. Moreover, the hyaline areas on the wing differ as follows: subtrapezoidal median area in cell cua ${ }_{1}$ extended anteriorly to vein $\mathrm{M}_{1}$, separated from hyaline area in cell $\mathrm{dm}$; two oblique areas from costal margin almost to or beyond vein $\mathrm{R}_{4+5}$, one proximal to and one distal to level of crossvein r-m; a circular area on basal part of cell $r_{4+5}$ and a triangular area on basal region of cell $\mathrm{m}_{1}$.

Description. Holotype male: measurements: $3.7 \mathrm{~mm}$ (body length), $3.1 \mathrm{~mm}$ (wing), $1.8 \mathrm{~mm}$ (abdomen). Head (Figs 7 and 8): Yellow, covered with whitish pollinosity. Scape and pedicel yellow. First flagellomere light brown. Arista brown. Clypeus, palpus and prementum yellow. Genal and postgenal setae weak. Postgena with short and white sparse setae. Thorax (Figs 5 and 6): Scutum, scutellum and postpronotal lobe yellow, covered with dense whitish pollinosity. Prosternum, proepimeron and proepisternum whitish-yellow. Anepisternum and dorsal half of anepimeron bright yellow. Katepisternum, ventral half of anepimeron, meron and katatergite bright dark brown. Anatergite and mediotergite dark brown covered with white pollinosity. Halter whitish on basal half and brown on the apical half. Legs: Yellow, except mid coxa, mid femur on basal third, and hind tibia brown. Fore femur with four and two spines on antero- and posteroventral surfaces, respectively. Mid femur on anteroventral surface with a row of spines beginning at base, and another on posteroventral surface beginning on apical third. Hind femur with spines from apical $2 / 5$ on antero- and posteroventral surfaces; anterodorsal seta absent. Wing (Fig. 1): Orange brown with margins bordering hyaline areas brown, and with the following hyaline areas: alula, anal lobe except distal margin, cells bm and cup and small areas aligned with them in cell br and $\mathrm{r}_{1}$, subtrapezoidal area at middle of cell cua ${ }_{1}$ extended to vein $\mathrm{M}_{1}$, two oblique areas from costal margin, one proximal to crossvein $r-m$ extended to vein $M_{1}$, slightly interrupted at vein $\mathrm{R}_{4+5}$, and another distal to r-m extended to at least $\mathrm{R}_{4+5}$, a circular area on basal part of cell $\mathrm{r}_{4+5}$, and triangular area on basal part of cell $\mathrm{m}_{1}$. Vein $\mathrm{R}_{2+3}$ slightly sinuous. Abdomen: Yellow, except brown band on basal fourth of syntergite 1+2; covered with black setulae (Fig. 9). Syntergite 

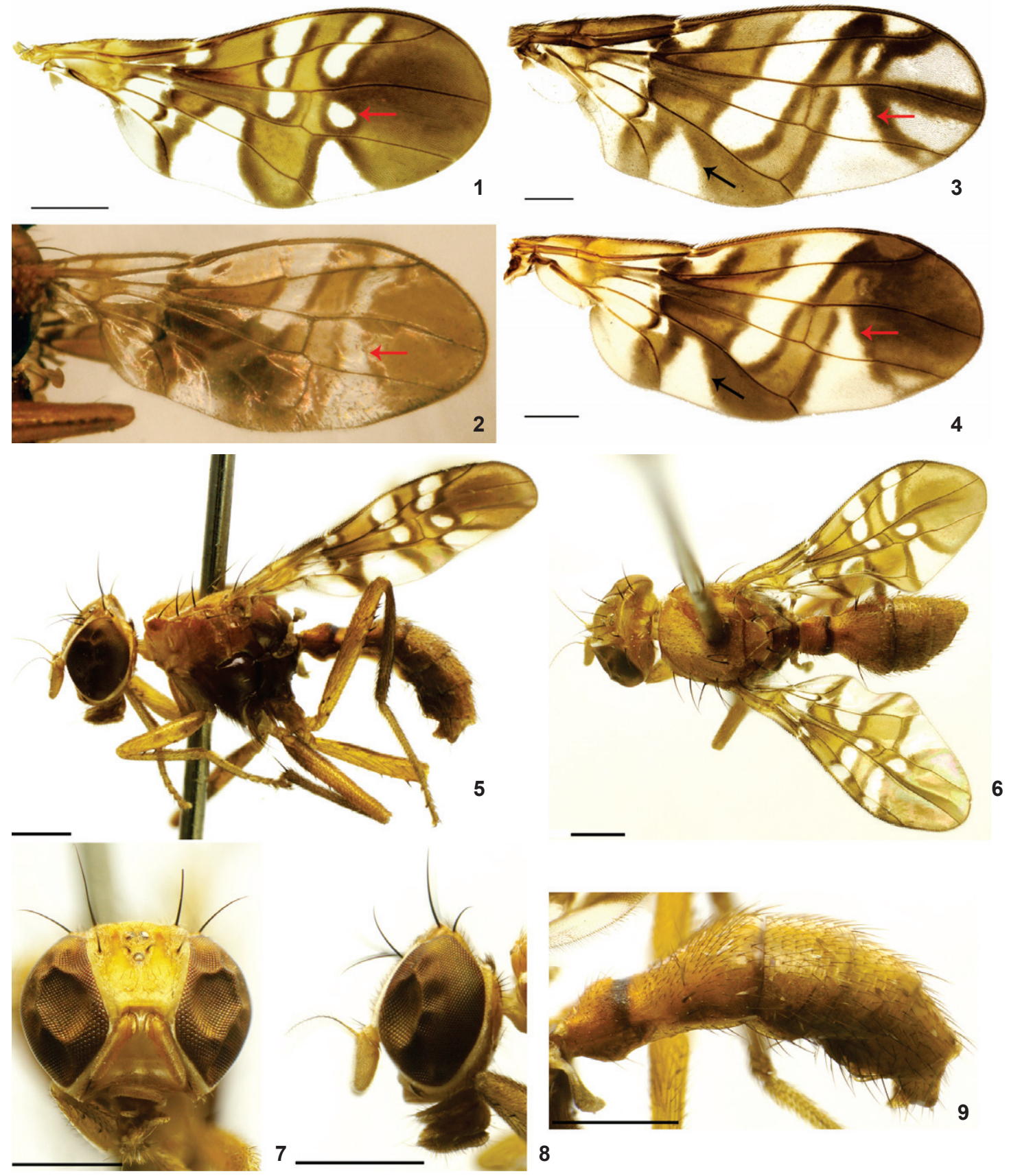

Figures 1-9. (1-4) Wings: (1) Hemixantha maculosa sp. nov., paratype male; (2) Hemixantha picta holotype female; (3-4) Hemixantha pulchripennis: (3) male; (4) female. Red arrows indicate hyaline areas on cell $r_{4+5}$; black arrows indicate subtriangular hyaline area at middle of cell cua1. (5-9) Hemixantha maculosa sp. nov., holotype male: (5) habitus, lateral; (6) habitus, dorsal; (7) head, frontal; (8) head, lateral; (9) abdomen, lateral. Scale bars: $0.5 \mathrm{~mm}$.

$1+2$ twice as wide at apex as at base; twice as long as tergite 3 . Tergites 3-5 gradually narrower than apex of syntergite $1+2$. Sternite 1 absent. Sternites 2-7 yellow; sternite 2 divided into two parts: anterior very reduced and slightly sclerotized, and posterior elongated, Y-shaped and relatively sclerotized; sternite 3 longer than wide, with base narrower than apex (Fig. 10); sternite 4 wider than long, subtrapezoidal (Fig. 10); sternite 5 developed, distinctly wider than long (Fig. 10). Sternite 6 short, 


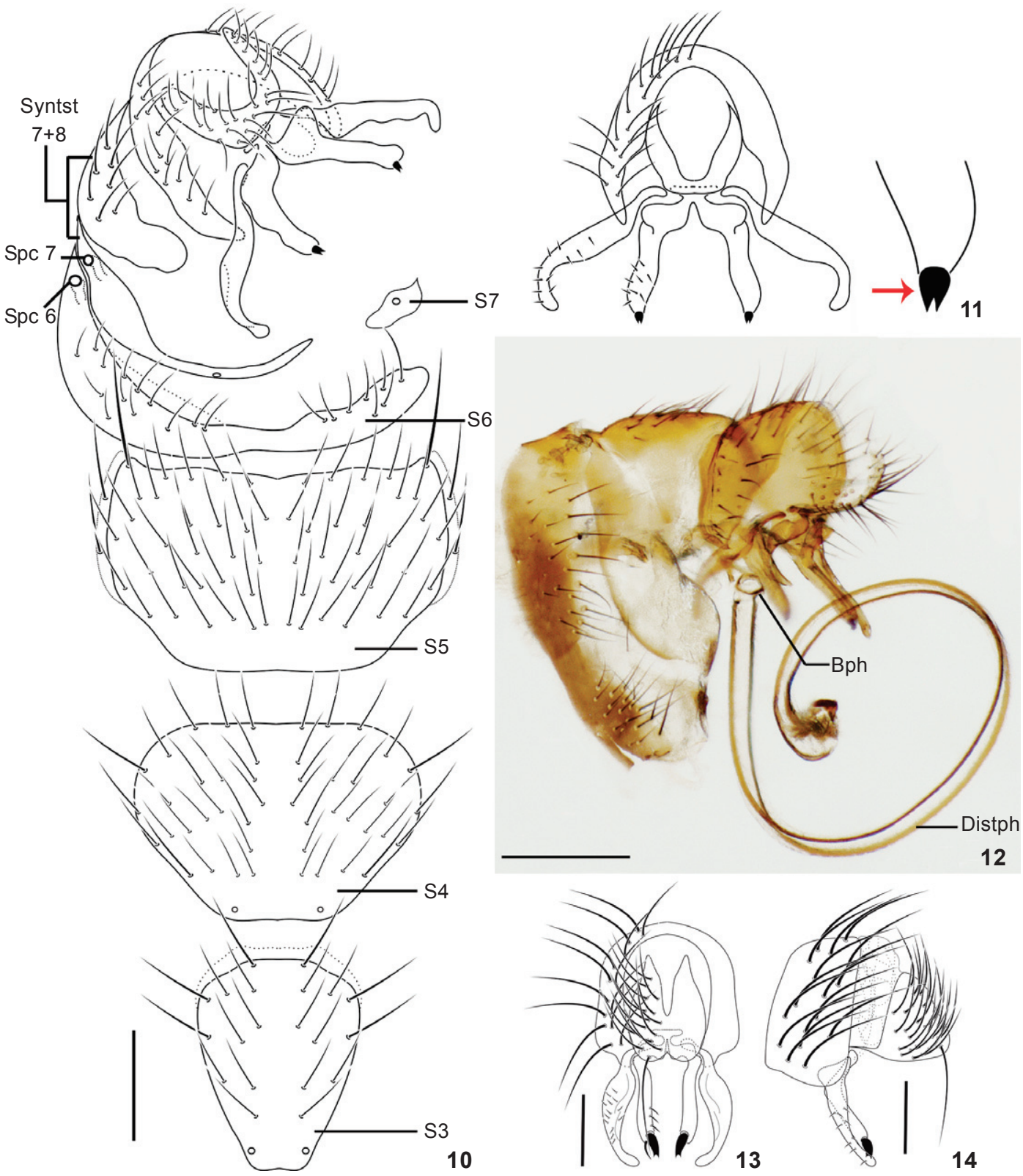

Figures 10-14. Male terminalia: (10-13) Hemixantha maculosa sp. nov., paratype: (10) sternites, epandrium, surstyli and proctiger, ventral view; (11) epandrium, lateral and medial surstylus, and proctiger, posterior view, in the right side prensiseta in detail (indicated by the red arrow); (12) sternite 6, syntergosternite 7+8, epandrium, surstyli, proctiger and phallus, lateral view; (13-14) Hemixantha pulchripennis epandrium, surstyli and proctiger: (13) posterior view; (14) lateral view. (Bph) Basiphalus, (Distph) distiphallus, (S) sternite, (Spc) spiracle, (Syntst) syntergosternite. Scale bars: $0.2 \mathrm{~mm}$.

very wide and ciliated (Fig. 10). Sternite 7 very reduced (Fig. 10). Terminalia (Figs 10-12): Lateral surstylus longer than medial surstylus, curved, without projection and medially wider than basal and apical parts; apex slender and distinctly curved (Fig. 11). Medial surstylus with a semicircular projection on anterior basal part (Fig. 11). Prensiseta slightly developed and symmetrically bifurcated apically, inserted on apex of medial surstylus (Fig. 11, indicated with red arrow). Proctiger slightly sclerotized, rounded and covered with setae of different lengths. Distiphallus long and flexible, with two sclerotized ribbons 

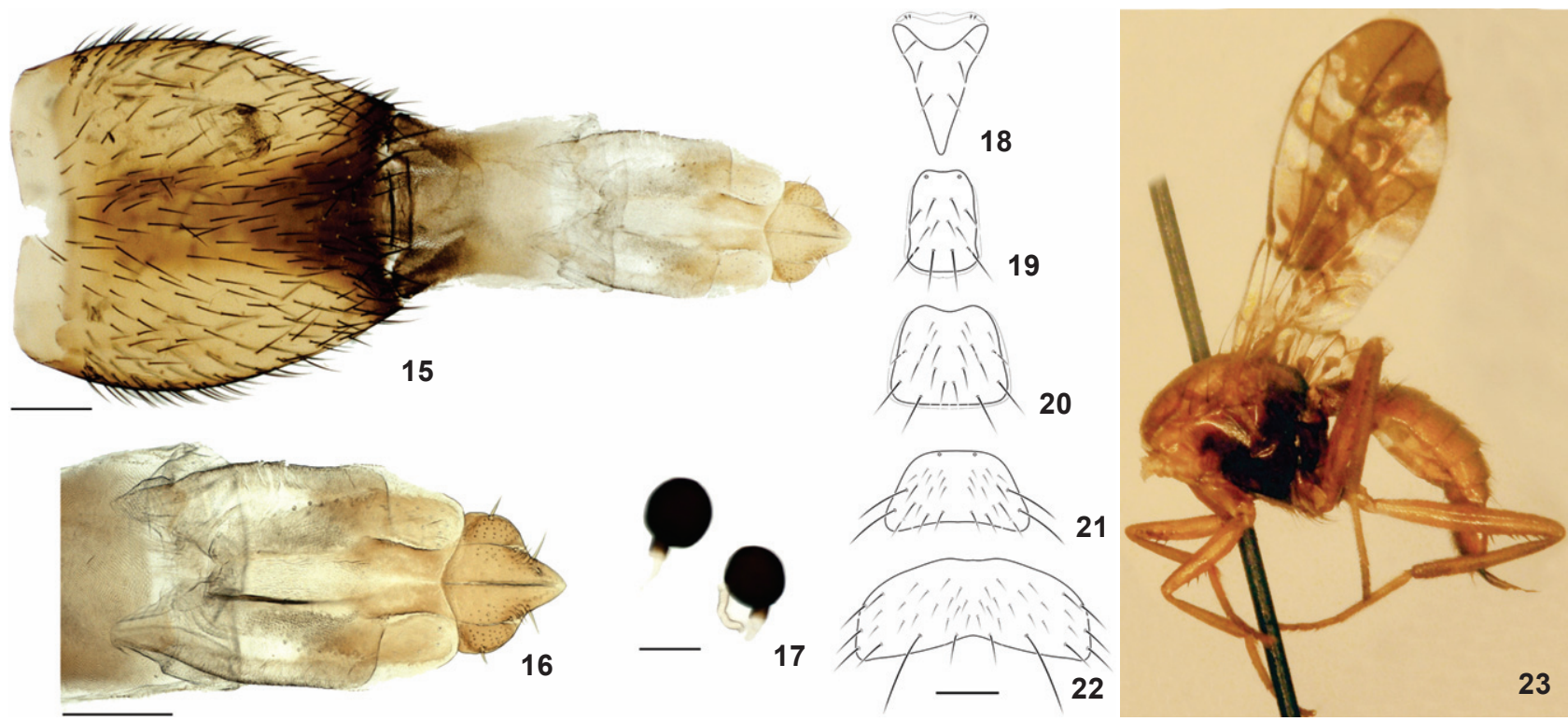

Figures 15-23. (15-22) Hemixantha maculosa sp. nov., paratype female, terminalia: (15) oviscape, eversible membrane, segment 8 and cerci; (16) segment 8 and cerci in detail; (17) spermathecae; (18) sternite 2; (19) sternite 3; (20) sternite 4; (21) sternite 5; (22) sternite 6. Scale bars: 15-16, 18-22: $0.1 \mathrm{~mm}$; 17: $0.05 \mathrm{~mm}$. (23) Hemixantha picta holotype female, habitus, lateral view.

connected by membrane; apex of one ribbon modified into a set of setae and with an asymmetrical and sclerotized plate (Fig. 12).

Variation. The paratype male from Taperinha, Pará (MZSP) is slightly different in the hyaline areas on the wing: basal part of cell $r_{1}$ with a small hyaline area, and the oblique area from costal margin, distal to r-m, is continuous to the circular area on basal part of cell $\mathrm{r}_{4+5}$, forming only a hyaline area.

Female: similar to male, except: the paratype from Bolivia (USNM) has mesopleura yellow, except for meron and katatergite brown. Abdomen (Figs 18-22): sternites 2-6 yellow; sternite 3 rectangular, longer than wide (Fig. 19); sternite 4 as wide as long, subtrapezoidal (Fig. 20); sternite 5 developed, distinctly wider than long (Fig. 21). Sternite 6 short and wide (Fig. 22). Terminalia (Figs 15-17): Oviscape $0.84 \mathrm{~mm}$ long, yellow, with longitudinal and central areas and apical margin brown (Fig. 15). Taenia brown, short, one-fifth as long as oviscape; slightly less sclerotized than oviscape. Eversible membrane brown and slightly sclerotized on basal $2 / 3$, hyaline and membranous on apical third (Fig. 15). Sternite $80.15 \mathrm{~mm}$ long, not fused, shorter than tergite 8. Cerci dome-shaped, enlarged at base and gradually narrower at apex (Fig. 16). Two spherical spermathecae (Fig. 17).

Material examined. Holotype male, MPEG: "BrasilPA[Pará] \Vitória do Xingú \Margem dir.[right margin of the river] - R.[river] Xingu $\backslash 12$ - 14-XII-2000" "Ilha [Island] Taboca \Mata de Várzea \Arm. [trap] Malaise 10\C. Maciel \& J. Dias [col.]". Remarks on the holotype: specimen in good condition, with no damage. Paratypes: same data as holotype (1 female, 1 male,
INPA; 1 female, 1 male, MPEG); Brazil, Pará, Santarém, Fazenda [Farm] Taperinha, x-xi.1970, Expedição Permante do Amazonas col. (1 male, MZSP); Bolivia, La Paz Province, Teoponte, San Juanito, $15^{\circ} 29^{\prime} 69^{\prime \prime} \mathrm{S} 67^{\circ} 47^{\prime} 80.3^{\prime \prime} \mathrm{W}$, 08.iv.2001, A.L. Norrbom col. (1 female, USNM).

Type locality. Taboca Island, Vitória do Xingu, Pará, Brazil. Geographic distribution. Brazil, Pará; Bolivia, La Paz Province.

Remarks. This is the first record of Hemixantha from the state of Pará.

Etymology. The specific epithet refers to the marks on the wing (from Latin maculosus = spotted).

\section{Hemixantha picta Hennig, 1937}

Figs 2, 23, 24

Hemixantha picta Hennig, 1937: 312. Holotype, female, Senckenberg Natural History Collections Dresden (Museum für Tierkunde). Type locality: Mapiri, Bolivia. Distribution: Bolivia. References: Hennig, 1937: 307 (key); Aczél, 1950: 27 (catalog); Steyskal, 1968: 5 (catalog).

Diagnosis. Similarly to $H$. pulchripennis, $H$. picta has the mesopleuron entirely brown. As in $H$. maculosa, the legs of $H$. picta are yellow, except for the mid and hind coxae brown. Nevertheless, the hyaline areas of the wing of $H$. picta are diagnostic: the wing has two complete transverse and slightly curved areas, one at the middle (proximal to r-m) extending to the posterior margin in cell $\mathrm{cu}_{1}$ and another at the apical third of the wing. 
Redescription. Holotype female (Fig. 23): Measurements (following HeNnig 1937: 312): $6.0 \mathrm{~mm}$ body length, without the head; $6.0 \mathrm{~mm}$ wing. Head: lost. Thorax: scutum, scutellum, proepimeron, proepisternum and prosternum yellow. Scutum and scutellum covered with whitish pollinosity. Mesopleuron and mediotergite bright brown. Posterior half of katatergite, anatergite and laterals of mediotergite with weak white pollinosity. Halter yellowish at basal half and brown at apical half. Legs: Yellow, except mid and hind coxae brown. Fore femur with spines beginning on preapical region. Mid femur on anteroventral surface with row of spines beginning at base and another on posteroventral surface beginning on apical third. Hind femur with spines from apical half; anterodorsal seta absent. Wing (Fig. 2): brown, except for the following hyaline areas: alula, basal fourth area, except for yellowish area at base of costal cell continuous until sub-base of cell br; sub-base of cell $r_{1}$; two complete transverse and slightly curved areas, one at the middle (proximal to r-m) extending to the posterior margin in cell $\mathrm{cu}_{1}$ and another at the apical third of the wing. Vein $\mathrm{R}_{2+3}$ straight. Abdomen: yellow with black setulae. Syntergite $1+2$ with four laterodorsal setae; apex twice wider than base; 2.3 times longer than tergite 3 . Tergites 3-5 slightly narrower than syntergite $1+2$. Sternites not observed. Terminalia: not dissected, observed only externally: oviscape at median region and taenia dark brown. Cerci domeshaped, enlarged at the base and gradually narrower at the apex (Fig. 24).

Male. Unknown.

Material examined. Holotype female, SMT: "Bolivia Mapiri \18.III.[19]03" "Hemixantha \picta [handwritten label]" "Staatl. Museum für \Tierkunde Dresden \Coll. W. SCHNUSE, 1911".

Geographic distribution: Bolivia.

Remarks on the holotype. Specimen in relatively good condition, except for the head, left mid and hind legs, which are missing.

\section{Hemixantha pulchripennis Hendel, 1911}

Figs 3-4, 13-14, 25-33

Hemixantha pulchripennis Hendel, 1911a: 262. Syntypes males, Hungarian Natural History Museum (Hendel, 1911a). Type locality: Manaus, Amazonas, Brazil. Distribution: Brazil. References: Hendel, 1911a: 258 (key), 1911b: plate 2 (figs 46-47, lateral habitus, head in frontal view); Hennig, 1937: 307 (key); Aczél, 1950: 27 (catalog); Steyskal, 1968: 5 (catalog).

Diagnosis. Hemixantha pulchripennis and $H$. picta have the mesopleuron entirely brown, but $H$. pulchripennis differs in having all coxae, fore femur, basal half of mid and hind femora, and mid and hind tibiae dark brown. Also, the pattern of the hyaline areas on the wing of $H$. pulchripennis (Fig. 3) differs considerably from the wing patterns of $H$. maculosa and $H$. picta: subtriangular or slightly oval area at middle of cell cua ${ }_{1}$ not extended anteri- orly beyond vein $\mathrm{cu}_{1}$ and separated from hyaline area in cell $\mathrm{dm}$ (Fig. 3, indicated with black arrow), wide transverse and oblique area at the middle of wing from the costal margin to cell $\mathrm{dm}$; subtriangular preapical area in cell $\mathrm{m}_{1}$ extended anteriorly to vein $\mathrm{R}_{4+5}$ (Fig. 3, indicated with red arrow); and three apical hyaline areas present only in males: one very reduced and subtriangular area in cell $r_{1}$, one subtrapezoidal area in cell $r_{2+3}$ and one smaller and subtrapezoidal area on cell $\mathrm{r}_{4+5}$ (Fig. 3).

Redescription. Male: Measurements $(\mathrm{n}=3): 5.5-6.8 \mathrm{~mm}$ (body length), 5.0-6.0 mm (wing), 2.7-3.1 mm (abdomen). Head: yellow, covered with whitish pollinosity. Scape and pedicel yellow. First flagellomere entirely brown or brown on dorsal half and yellow on ventral half. Arista brown. Clypeus and prementum yellow. Palpus yellow or brown. Genal and postgenal setae weak. Postgena with short and white sparse setae. Thorax: scutum, scutellum on dorsal surface, proepimeron, proepisternum and prosternum yellow. Scutum and scutellum covered with dense whitish pollinosity. Mesopleuron, metapleuron, mediotergite and scutellum on ventral surface bright dark brown. Posterior half of katatergite, anatergite and lateral of mediotergite with weak white pollinosity. Halter yellowish on basal half and brown on apical half. Legs: coxae, basal half of fore femur, or entire fore femur, mid femur on basal half, hind femur on second quarter portion, mid and hind tibiae dark brown. Trochanter, sometimes fore femur on apical half, fore tibia, mid femur on apical half, hind femur on first fourth and apical half, and tarsomeres yellow. Fore femur with spines from apical third. Mid femur on anteroventral surface with row of spines beginning at base and another on posteroventral surface beginning on apical half. Hind femur with spines from apical half; anterodorsal preapical seta weak. Wing (Fig. 3): brown, except by the following hyaline areas: alula, base of br, base and sub-base of cell $r_{1}$, cells bm and cup, basal half of anal lobe, subtriangular or slightly oval area at middle of cell cua ${ }_{1}$ not extended anteriorly beyond vein $\mathrm{cu}_{1}$ and separated from hyaline area in cell dm (Fig. 3, indicated with black arrow), a wide transversal and oblique area at middle of wing from costal margin to cell dm, subtriangular preapical area in cell $\mathrm{m}_{1}$ extended anteriorly to vein $\mathrm{R}_{4+5}$ (Fig. 3 , indicated with red arrow); and three apical hyaline areas: one very reduced and subtriangular area in cell $\mathrm{r}_{1}$, one subtrapezoidal area in cell $\mathrm{r}_{2+3}$ and one smaller and subtrapezoidal area on cell $\mathrm{r}_{4+5}$. Vein $\mathrm{R}_{2+3}$ straight. Terminalia (Figs 13 and 14): lateral surstylus slightly larger than medial surstylus; lateral surstylus without projection and on median region wider than basal and apical regions; medial surstylus with slightly semicircular projection on anterior basal region; prensiseta distinctly stronger (Fig. 13) than in H. maculosa (Fig. 11), symmetrically bifurcated at the apex, inserted at the apex of medial surstylus; proctiger slightly sclerotized, very developed, rounded, covered with long setae and with a distinct long pair of setae on ventral surface (Figs 13 and 14); distiphallus similar to H. maculosa.

Comments. According to Hendel (1911a), two syntypes males of Hemixantha pulchripennis are deposited at the Hun- 

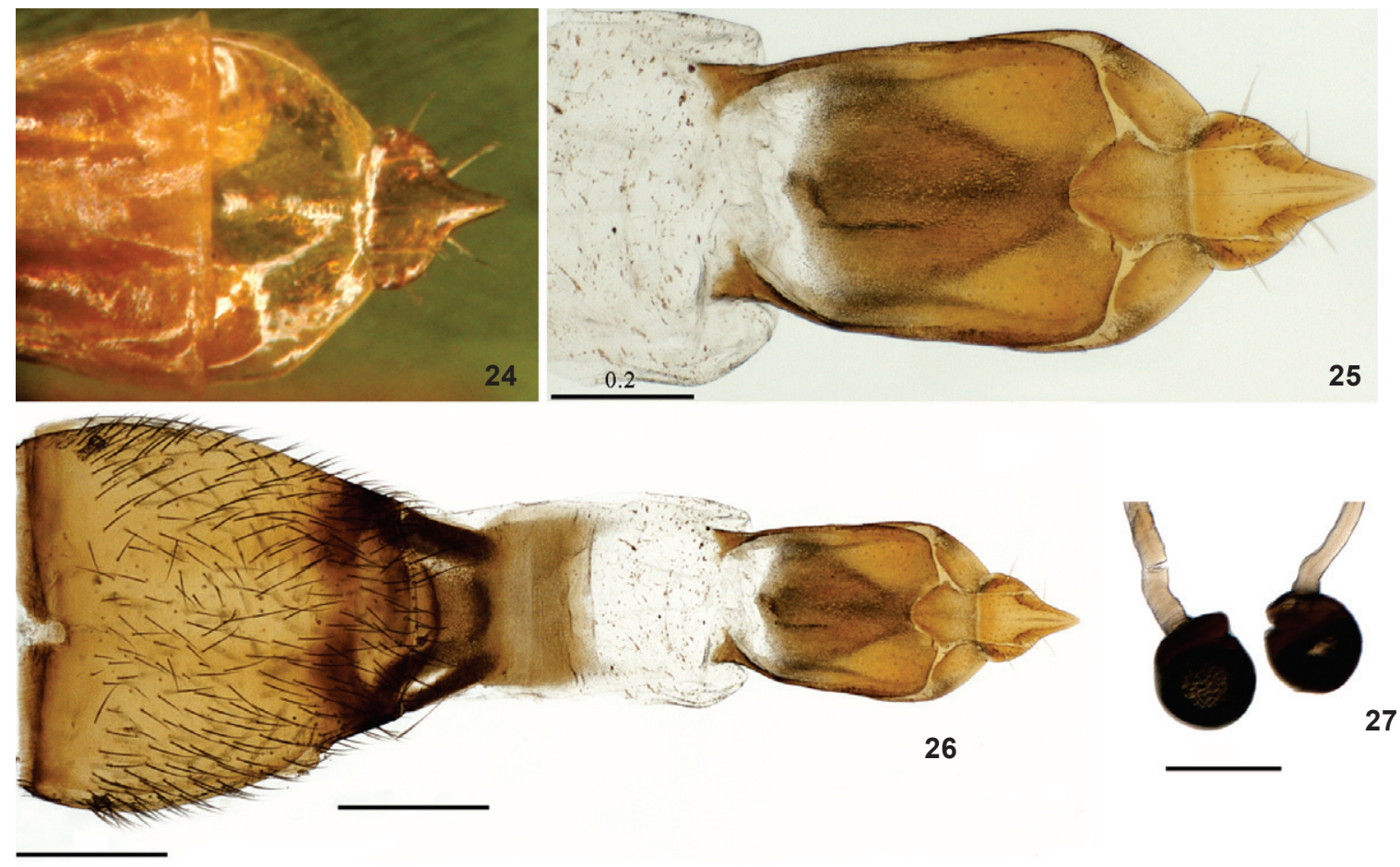

$0 \quad 0 \quad \mathbf{2 8}$

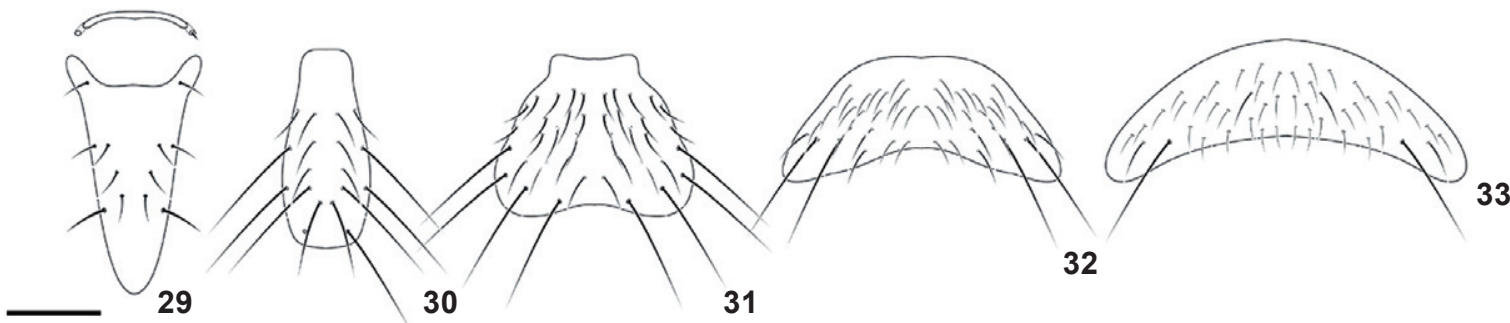

Figures 24-33. (24) Hemixantha picta holotype female, terminalia; (25-33) Hemixantha pulchripennis female: (25) segment 8 and cerci; (26) oviscape, eversible membrane, segment 8 and cerci; (27) spermathecae; (28) sternite 1; (29) sternite 2; (30) sternite 3; (31) sternite $4 ;$ (32) sternite $5 ;(33)$ sternite 6 . Scale bars: $25,29-33=0.2 \mathrm{~mm} ; 26,28=0.5 ; 27=0.1$

garian Natural History Museum, Budapest, Hungary. Because the institution does not lend type material, we could not study the syntypes of this species. However, Hendel (1911a, b) provided a reasonably detailed description and an excellent figure of the habitus of $H$. pulchripennis in profile, which allowed us to reliably identify this species. Also, the specimens we used in the redescription are from the type locality. Before this contribution, only the male of $H$. pulchripennis was known. Fortunately, we found females in the INPA collection from the type locality (Manaus, Brazil). Females are similar to males, except for differences in the hyaline areas of the wing (Figs 3 and 4), as following described. Measurements $(\mathrm{n}=2)$ : $5.0-6.0 \mathrm{~mm}$ (body length), 4.5-5.0 $\mathrm{mm}$ (wing), 2.6-2.9 $\mathrm{mm}$ (abdomen). Wing (Fig. 4): brown, except for the following hyaline areas: alula, base of cell br, base and sub-base of cell $r_{1}$; cells bm and cup, basal half of anal lobe, subtriangular or slightly oval median area on cell cua ${ }_{1}$ (Fig. 4, indicated with black arrow), a wide transverse and oblique median area from the costal margin to cell $\mathrm{dm}$, triangular preapical area from $\mathrm{R}_{4+5}$ to posterior margin of wing (Fig. 4, indicated with red arrow); apical fourth completely brown, without hyaline areas (Fig. 4). Abdomen: yellow, with brown band on basal fourth of syntergite $1+2$; covered with black setulae. Syntergite $1+21.5$ times wider at apex than at base; 2.5 times longer than tergite 3 . Tergites 3-5 gradually narrower than apex of syntergite $1+2$. Sternites $1-6$ yellow; sternite 1 present, but reduced into two very small subcircular plates and weakly sclerotized (Fig. 28); sternite 2 divided into two portions: anterior very reduced and slightly 
scletotized and posterior elongated, gradually narrower and relatively sclerotized (Fig. 29); sternite 3 longer than wide, with base narrower than apex (Fig. 30); sternite 4 wider than long, with subtrapezoidal shape (Fig. 31); sternite 5-6 distinctly wider than long (Figs 32 and 33). Terminalia: oviscape $1.2 \mathrm{~mm}$ long, light brown (Fig. 26). Taenia dark brown, short, one sixth as long as oviscape, as sclerotized as oviscape. Eversible membrane brown and slightly sclerotized on basal half; hyaline and membranous on apical half (Fig. 26). Sternite $80.2 \mathrm{~mm}$ long, completely fused, slightly shorter than tergite 8 (Fig. 25). Cerci dome-shaped, with enlarged base and apex gradually narrowed (Fig. 25). Two spherical spermathecae (Fig. 27).

Material examined. BraziL, Amazonas: Manaus, 16.VII.1969, E.V. Silva leg., 1 female (INPA); idem, 31.III.1977, L. Albuquerque leg., 1 female (INPA); idem, Campus Universitário (UFAM), 20.VIII.1978, J.A. Rafael leg., 1 male (INPA); idem, 14.X.1978, idem, 1 male (INPA), idem, Reserva Km 41 (area 1501, Esteio farm, $2^{\circ} 26^{\prime} 56^{\prime \prime} \mathrm{S}, 59^{\circ} 46^{\prime} 12^{\prime \prime} \mathrm{W}$ ), PDBFF (Biological Dynamics of Forest Fragments Project, Sub-bosque), 18-19.IX.2004, R. Querino leg., (1 male, INPA).

Geographical distribution. Northern portion of Brazil (state of Amazonas).

\section{DISCUSSION}

Hemixantha had 19 species and one subspecies known and now it is composed by 20 species and one subspecies. Hemixantha maculosa sp. nov., H. picta and $H$. pulchripennis are easily distinguished from all other species of Hemixantha by the spots on the wing forming an extensively banded pattern. And these three species differ considerably from each other in the pattern of the spots on the wing, and in the coloration of pleuron and legs. The sexual dimorphism can be observed in species of some genera of Richardiidae, for instance in Richardia Robineau-Desvoidy, 1830, Megalothoraca Hendel, 1911 and Batrachophthalmum Hendel, 1911, and the differences between the sexes are present in the head shape or the spines on the legs (only in Richardia). The sexual dimorphism found in $H$. pulchripennis is for first time reported to the genus; moreover, the difference in the spots on the wing is for the first time found in Richardiinae. This attribute is also found in Automola Loew, 1873 (Epiplateinae).

\section{ACKNOWLEDGEMENTS}

We sincerely thank Augusto L. Henriques (INPA), Orlando T. Silveira (MPEG), Carlos J. Einicker Lamas (MZSP), Allen L. Norrbom (USNM) for lending material. L.D. Wendt thanks Uwe Kallweit for welcoming her at SMT and allowing inspection of the type material of $H$. picta. We also thank Coordenação de Aperfeiçoamento de Pessoal de Nível Superior (CAPES) and Fundação de Amparo à Pesquisa do Estado do Amazonas (FAPEAM) for the scholarship provided and for supporting the project "Incremento do conhecimento da diversidade, formação e fixação de especialistas em Sistemática de Diptera (Insecta) na Amazônia". R. Ale-Rocha thanks Conselho Nacional de Desenvolvimento Científico e Tecnológico for the fellowship (PQ/CNPq) provided. The visit to SMT by L.D. Wendt was funded by the German Academic Exchange Service (DAAD) and CNPq. Automontage equipment was available to us through the project "Amazonas: Diversidade de insetos ao longo de suas fronteiras" (PRONEX/FAPEAM Proc. 1437/2007/ NTO318/07) headed by Dr. José Albertino Rafael.

\section{LITERATURE CITED}

Alencar, B. De A.; L.D.Wendt \& R. Ale-Rocha. 2013. Richardia Robineau-Desvoidy (Diptera, Tephritoidea, Richardiidae) from Central Amazon, Brazil. Revista Brasileira de Entomologia 57: 202-208.

AczéL, M. 1950. Catalogo de la sufamilia americana "Richardiinae"(Dipt. Acalypt. Otitidae). Acta Zoologica Lilloana 9: 5-47.

Carvalho, C.J.B. de; M. WolfF \& L.D. Wendt. 2011. A new stalkeyed species of Batrachophthalmum Hendel (Diptera, Richardiidae) from Colombia. Zootaxa 2932: 41-46.

Cumming, J.M. \& D.M. Wood. 2009. Morphology and terminology, p. 9-50. In: B.V. Brown; A. Borkent; J.M. Cumming; D.M. Wood; N.E. Woodley; M.A. Zumbado (Eds). Manual of Central American Diptera. Ottawa, NRC Research Press, vol. 1.

Greene, E.; L.J. Orsak \& D.W. Whitman. 1987. A tephritid fly mimics the territorial displays of its jumping spider predators. Science 236: 310-312.

Hancock, E.G. 2010. Richardiidae (Richardiid flies), p. 871-879. In: B.V. Brown; A. Borkent; J.M. Cumming; D.M. Wood; N.E. Woodley; M.A. Zumbado (Eds). Manual of Central America Diptera. Ottawa, NRC Research Press, vol. 2.

Hendel, F. 1911a. Die arten der Dipteren-Subfamilie Richardiinae. Deutsche Entomologische Zeitschrift 1911: 181-212, 239270, 367-396.

HeNDEL, F. 1911b. Diptera. Fam. Muscaridae, Subfam. Richardiinae. Genera Insectorum 113: 1-56.

HeNNIG, W. 1937. Beiträge zur Systematik der Richardiiden (Dipt.). Revista de Entomologia 7 (2-3): 21-34; 306-312; 484-486.

Hennig, W. 1938. Neue Beiträge zur Systematik der Richardiiden und Tyiiden. Arbeiten über Morphologische und Taxonomische Entomologie aus Berlin-Dahlem 5 (1): 7-15.

Loew, H. 1873. Monographs of the Diptera of North America. Part III. Smithsonian Miscellaneous Collection 256: 1-358.

MATHER, M. \& B. RotTeberG. 1987. A sheep in wolf's clothing: tephritid mimic spider predators. Science 236 (4799): 308-310.

Perez-Gelabert, D.E. \& F.C. Thompson. 2006. A new genus and species of Richardiidae (Diptera) from Hispaniola. Zootaxa 1259: 25-31.

Sivinski, J. 1999. Breeding habits and sex in families closely related to the Tephritidae: opportunities for comparative 
studies of the evolution of fruit fly behavior, p. 23-37. In: M. Aluja \& A.L. Norrbom (Eds). Fruit flies (Tephritidae): Phylogeny and evolution of behavior. Boca Raton, CRC Press, 994p.

Sivinski, J. \& R. PereIRA. 2005. Do wing markings in fruit flies (Diptera: Tephritidae) have sexual significance? Florida Entomologist 88 (3): 321-324.

Sivinski, J. \& J.C. Wевв. 1986. Changes in a Caribbean fruit fly acoustic signal with social situation (Diptera: Tephritidae). Annals of Entomological Society of America 79 (1): 146-149.

SteYskal, G.C. 1968. Family Richardiidae, p. 1-20. In: E.P. VANZoline $\&$ N. Papavero (Eds). A catalogue of the Diptera of the Americas south of the United States. São Paulo, Departa- mento de Zoologia, Secretaria da Agricultura.

Wendt, L.D. \& R. Ale-Rocha. 2012. Redescription of the genus Coniceps Loew, 1873 (Diptera, Richardiidae). Zootaxa 3238: 49-56.

White, I.M. 1999. Morphological features of the Tribe Dacini (Dacinae): their significance to behavior and classification, p. 505-546. In: M. Aluja \& A.L. Norrbom (Eds). Fruit flies (Tephritidae): Phylogeny and evolution of behavior. Boca Raton, CRC Press, 994p.

White, I.M.; D.H. Headrick; A.L. Norrbom \& L.E. Carrol. 1999. Glossary, p. 881-924. In: M. Aluja \& A.L. NorRbom (Eds). Fruit flies (Tephritidae): Phylogeny and evolution of behavior. Boca Raton, CRC Press, 994p.

Submitted: 12.VII.2013; Accepted: 09.IX.2013.

Editorial responsibility: Gabriel L.F. Mejdalani 